\title{
Inhibition of Bacteria Contaminating Alcoholic Fermentations by Killer Yeasts
}

\author{
Maria Cristina Meneghin ${ }^{1,2}$, Vanda Renata Reis ${ }^{1,2}$ and Sandra Regina Ceccato-Antonini ${ }^{1 *}$ \\ ${ }^{I}$ Departamento de Tecnologia Agroindustrial e Sócio-Economia Rural; Centro de Ciências Agrárias; Universidade \\ Federal de São Carlos; Via Anhanguera, Km 174; 13600-970; Araras - SP - Brasil. ${ }^{2}$ Programa de Pós-graduação \\ em Ciência e Tecnologia de Alimentos; Universidade de São Paulo; São Paulo - SP - Brasil
}

\begin{abstract}
The aim of this work was to study the in vitro antibacterial activity possessed by killer yeast strains against bacteria contaminating alcoholic fermentation (Bacillus subtilis, Lactobacillus plantarum, Lactobacillus fermentum and Leuconostoc mesenteroides), in cell X cell and cell X crude toxin preparations. The bacteria were not inhibited by any S. cerevisiae killer strains (5 out of 11). The inhibition caused by two crude toxin preparations (Trichosporon figueirae and Candida sp) against L. plantarum was surprisingly high but not in the same extent for B. subtilis, especially with three killer strains (Candida glabrata, Pichia anomala and Candida sp). L. mesenteroides and L. fermentum strains were neither inhibited in cell X cell nor crude toxin X cell tests. The results suggested that killer activity of yeasts might operate over bacteria and it could be used for the biocontrol of contaminating bacteria from alcoholic fermentation if additional tests on toxin application in fermentation shown to be successful. A wider panel of S. cerevisiae killer strains should be used to confirm that they were really unable to control the growth of these Gram-positive bacteria.
\end{abstract}

Key words: Bacteria, killer yeasts, alcohol, fermentation

\section{INTRODUCTION}

The industrial process for bioethanol production is a nonsterile open activity that uses sugar cane juice and/or molasses as substrate for yeast fermentation with cell recycle (Wheals et al., 1990). The use of crude cane must promote a continuous input of microorganisms into the process, demanding chemicals and causing operational problems in centrifuges and heat exchangers, due mainly to flocculation in the yeast suspension caused by contaminating bacteria (Yokoya and Oliva-Neto, 1991; Rodini, 1985; Nobre et al., 2007). The secretion of antimicrobial factors by yeasts involving killer strains, which produce a toxin that is lethal to sensitive microorganisms, is an interesting approach to the biocontrol of contaminant bacteria from fermentation process.

Killer toxins (mycocins) were first observed in strains of Saccharomyces cerevisiae by Bevan and Makower (1963) but yeast strains belonging to species of the genera Debaryomyces, Hanseniaspora, Kluyveromyces, Pichia, Schwanniomyces, Williopsis, Cryptococcus, Metschnikowia and Candida have been also found to be toxin-producers (Young and Yagiu, 1978; Sawant et al., 1989; Golubev, 1998).

Killer yeasts are immune to the activity of their own killer toxins. According to Buzzini et al. (2007), all killer toxins studied so far have been found to be protein or glycoproteins with

\footnotetext{
*Author for correspondence: antonini@cca.ufscar.br
} 
molecular weights ranging from 5000-10,000 to $100,000 \mathrm{Da}$ or even greater in a few cases. The mechanism of action of killer toxins varies from cell cycle arrest in G1 phase, increased membrane permeability to ions, formation of ion channel, plasma membrane damage or inhibition of glucan synthesis (Kagan, 1983; Izgu and Altinbay, 2004; Buzzini et al., 2007).

Initial observations had limited the activity of killer toxins to yeasts, but this action could be displayed against a great variety of unrelated eukaryotic and prokaryotic microorganisms (Morace et al., 1989; Provost et al., 1995). Some potential uses of the killer phenomenon have been proposed as biocontrol against spoilage yeasts and moulds in fermentation processes and food preservation (Palpacelli et al., 1991; Michalcakova et al., 1993; Coelho et al., 2007); biotyping of yeasts (Buzzini and Martini, 2001; Buzzini et al., 2004, 2007; Tosta, 2004) with special interest in biomedical and industrial applications; and as novel antimycotic agents (Sawant et al., 1989; Buzzini et al., 2004). An extensive review on yeast killer systems is found in Magliani et al. (1997). The yeast killer system was also applied for differentiation of etiological agents of nocardiosis and Gram-positive pathogenic bacteria (Morace et al., 1989; Izgu and Altinbay, 1997; Fuentefria et al., 2008).

In this context, this work aimed to study the in vitro antibacterial activity possessed by killer yeast strains against Gram-positive bacteria contaminating alcoholic fermentation, especially Lactobacillus plantarum, in cell X cell and cell X crude toxin preparations.

\section{MATERIALS AND METHODS}

\section{Microorganisms}

The strains of killer yeasts used are listed in Table 1. These were maintained in YEPD Agar medium (yeast extract $1 \%$; bacteriological peptone $2 \%$; glucose $2 \%$; agar $2 \%$ ) at $4^{\circ} \mathrm{C}$. The killer activity was determined by the production of an inhibition or blue zone around the killer strain when inoculated with the sensitive strains CCA003 (NCYC1006, Saccharomyces cerevisiae) or CCA039 (ATCC15126, Torulopsis glabrata), onto buffered-YEPD-methylene blue medium (citrate-phosphate buffer, $\mathrm{pH} 4.5-4.7,2 \mathrm{~mL} / \mathrm{L}$ of $1.5 \%$ methylene blue solution).
The following bacterial strains were used in experiments: Bacillus subtilis ATCC6051 (CCT 2471); Lactobacillus fermentum ATCC9338 (CCT0559); Leuconostoc mesenteroides ATCC19255 (CCT5852); Lactobacillus plantarum ATCC8014 (CCT0580). They were inoculated in appropriate culture media as MRS (dextrose 2\%; bacteriological peptone $1 \%$; meat extract $1 \%$; yeast extract $0.5 \%$; sodium acetate $0.5 \%$; ammonium citrate $0.2 \%$; potassium phosphate $0.2 \%$; magnesium sulphate $0.2 \%$; manganese sulphate $0.005 \%$; Tween $800.001 \%$; agar $2 \%$ ) for Lactobacillus species at $37^{\circ} \mathrm{C}$, and nutrient agar (bacteriological peptone $0.5 \%$; meat extract $0.3 \%$; sodium chloride $0.1 \%$; agar $2 \%$ ) for the others at $30^{\circ} \mathrm{C}$. After growth, they were kept in the same medium at $4^{\circ} \mathrm{C}$.

\section{Killer activity in cell $X$ cell tests}

The sensitivity tests were performed in Nutrient Agar or MRS media, spreading $100 \mu \mathrm{L}$ of the bacterial suspension and inoculating the killer yeast strains with sterile toothpicks on the medium surface, in triplicate, following incubation at $30^{\circ} \mathrm{C}$ for two days. An inhibition zone around the killer yeast colony characterized bacterial sensitivity (positive result).

\section{Killer activity in cell $X$ crude toxin tests}

Initially, the growth curves of four killer yeast strains (CCA194, CCA199, CCA417 and CCA630) were determined as following. Two loops of each strain was inoculated in $20 \mathrm{~mL}$ of buffered-YEPD broth (citrate-phosphate buffer, $\mathrm{pH}$ 4.5-4.7) and incubated overnight at $30^{\circ} \mathrm{C}$ and $160 \mathrm{rpm}$. This was transferred to a $1000-\mathrm{ml}$ Erlenmeyer containing $180 \mathrm{ml}$ of buffered-YEPD broth $(10 \%$ inoculum vol/vol), which was incubated at $30^{\circ} \mathrm{C}$ at $40 \mathrm{rpm}$ for 48 hours. Samples were periodically taken to determine the optical density at $600 \mathrm{~nm}$ in a Thermo ${ }^{\circledR}$ Biomate-3 spectrophotometer. The sample was filtered through $0.45-\mu \mathrm{m}$ membrane to obtain a crude toxin preparation. Values of $\mathrm{pH}$ were determined in a digital $\mathrm{pH}$-meter and filtrates were kept in freezer. The killer activity of crude toxin preparations was confirmed by spreading $100 \mu \mathrm{L}$ of suspension of the sensitive strains (CCA003 and CCA039) on buffered-YEPD-methylene blue medium and after drying, 10-mm wells onto the medium were filled with $50 \mu \mathrm{L}$ of crude toxin preparations. Petri dishes were incubated at $25^{\circ} \mathrm{C}$ for two days and 
inhibition and/or blue zone around the wells were measured.

The killer activity using crude toxin preparations and bacterial strains were performed as above; however, Nutrient Agar medium was used for $L$. mesenteroides and $B$. subtilis, while for Lactobacillus, MRS medium was utilized. All the experiments were incubated at $25^{\circ} \mathrm{C}$, with inhibition zone measurements after two days.

\section{RESULTS AND DISCUSSION}

The sensitivity tests of bacterial strains against killer yeasts are presented in Table 2 . The bacteria were not inhibited by any $S$. cerevisiae killer strains. Izgu and Altinbay (1997) found that toxins of killer Saccharomyces cerevisiae were not active against bacterial strains. Polonelli and Morace (1986) had described the killer effect of 36 strains of Hansenula, Pichia, Saccharomyces and Candida on bacterial isolates, but Saccharomyces was only capable to inhibit Gram-negative bacteria.

The nature of the interaction(s) between the killer yeasts and strains of other microbial groups still remains to be elucidated. Buzzini et al. (2007) considered that different cell wall composition occurs in microbial groups other than fungi and it appeared likely that the secretion of nonproteinaceous inhibitory molecules was the most probable mechanism. Killer toxin labels for S. cerevisiae were $\mathrm{K} 1, \mathrm{~K} 2$ and $\mathrm{K} 28$, whose genetic basis were dsRNA, all exhibiting $\beta$-(1,6)-glucan and mannoproteins as primary receptors at the cell wall level.

Table 1 - Killer yeast strains.

\begin{tabular}{ll}
\hline Code & Yeast characteristics and identification \\
\hline CCA004 & Saccharomyces cerevisiae, NCYC 738, K2 toxin \\
CCA008 & Saccharomyces cerevisiae \\
CCA015 & Saccharomyces cerevisiae, isolated from alcoholic fermentation \\
CCA176 & Saccharomyces cerevisiae, strain $\Sigma 1278 b$, mat a/mat $\alpha$ \\
CCA194 & Candida glabrata, NCYC388 (CCT2369), K4 toxin \\
CCA199 & Pichia anomala, NCYC435 (CCT4373), K8 toxin \\
CCA231 & Saccharomyces cerevisiae, isolated from alcoholic fermentation \\
CCA369 & Candida tropicalis, isolated from alcoholic fermentation (inoculum) \\
CCA417 & Candida sp., isolated from alcoholic fermentation (inoculum) \\
CCA510 & Kluyveromyces marxianus, isolated from alcoholic fermentation (fermented must) \\
CCA630 & Trichosporon figueirae, isolated from alcoholic fermentation (fermented must) \\
\hline
\end{tabular}

NCYC=National Collection of Yeast Cultures; CCT=Coleção de Culturas Tropical

Table 2 - Bacterial sensitivity to killer yeast strains in cell X cell tests, at $30^{\circ} \mathrm{C}$. $\mathrm{LF}=$ Lactobacillus fermentum; LM = Leuconostoc mesenteroides; $\mathrm{LP}=$ Lactobacillus plantarum; $\mathrm{BS}=$ Bacillus subtilis.

\begin{tabular}{cccccccccccc}
\hline Bacteria & \multicolumn{10}{c}{ Killer strains } \\
\cline { 2 - 13 } & 004 & 008 & 015 & 176 & 194 & 199 & 231 & 369 & 417 & 510 & 630 \\
\hline LF & - & - & - & - & - & - & - & - & - & - & - \\
LM & - & - & - & - & - & - & - & - & - & - & - \\
LP & - & - & - & - & + & + & - & - & + & - & + \\
BS & - & - & - & - & + & + & - & - & + & - & + \\
\hline
\end{tabular}

Legend: (-) no inhibition zone (+) inhibition zone

Antibacterial products secreted by yeasts are not common, especially in $S$. cerevisiae. Sasaki et al. (1984) screened 150 strains of Saccharomyces for inhibitory activity against Gram-positive and Gram-negative bacteria and found only eleven yeasts inhibiting all tested bacteria. In contrast, when surveying nearly 400 yeast strains belonging to 31 genera for their antibacterial activity, Bilinski et al. (1985) found only two species (Kluyveromyces thermotolerans and Kloeckera 
apiculata) to possess activity against $L$. plantarum and Bacillus cereus. The authors demonstrated no adverse effects against Gram-negative bacteria.

Oliva-Neto et al. (2004) described a Saccharomyces strain (M26) that presented an inhibitory halo against $L$. fermentum culture and significant reduction in the culture turbidity and specific growth rate. However, they did not attribute this inhibition to the killer activity, but to complex substances from yeast secondary metabolism and succinic acid released in large quantities, as already observed by other authors (Bilinski et al., 1985; Basso et al., 1996).

The Gram-positive bacteria $L$. plantarum, $L$. fermentum, L.mesenteroides and B. subtilis were chosen mainly due to their importance as contaminants in alcoholic fermentations (Amorim and Oliveira, 1982; Rodini, 1985; Silva, 1988). According to Rodini (1985), Gram-positive bacteria account for $65 \%$ of total number in alcoholic fermentations. Proportions of 38, 12 and $3 \%$ were found, respectively, for Lactobacillus, Leuconostoc and Bacillus in sugar cane juice after clarification, pasteurization and cooling processes (Silva, 1988). Among the yeast strains, CCA194, CCA199, CCA417 and CCA630 showed inhibition potential against bacteria, so they were also selected for additional tests.

The killer strains were grown in buffered-YEPD medium for $48 \mathrm{~h}$ (Fig. 1) and free-cell filtrates were tested against the sensitive yeasts (Fig. 2) and bacterial strains (Fig. 3). Results in Fig. 2 have confirmed the killer activity of yeast filtrates from $6 \mathrm{~h}$ of cultivation, with high stability of toxicity during $48 \mathrm{~h}$. The inhibition caused by the killer yeasts CCA4 17 and CCA630 against $L$. plantarum was surprisingly high (Fig. 3).

Crude toxin preparation from CCA194 (C. glabrata) inhibited $L$. plantarum after $24 \mathrm{~h}$ of killer yeast growth; with CCA199 ( $P$. anomala), there was a small clear inhibition zone from the beginning of cultivation, which might be explained either by the fast growth of the yeast (log phase between 4-12 h) or by the low medium $\mathrm{pH}$ (4.5-
4.7). In spite of using a buffered medium, which potentializes the killer toxin production, $\mathrm{pH}$ measurements were taken along the cultivation to assure that the inhibition could not be attributed to the $\mathrm{pH}$ decrease. In fact, this could be observed at the initial crude toxin preparations against bacteria, but the inhibition zone grew significantly although medium $\mathrm{pH}$ did not vary at all. With CCA417 (Candida sp), the same effect was observed. The last killer yeast and CCA630 (T. figueirae) were found to be great $L$. plantarum inhibitors (Fig. 3).

The killer phenomenon has already been reported for several species of the genus Trichosporon (Golubev, 2006), shown to possess a killer profile against 100 isolates of Cryptococcus neoformans / Cryptococcus gattii (Fuentefria et al., 2007) and was able to inhibit and discriminate sensitive strains of Staphylococcus epidermidis (Fuentefria et al., 2008).

Lactobacillus is highly adapted to the nutritional conditions and alcohol concentration in tanks, causing serious yeast flocculation problems, resulting in viability decrease of $S$. cerevisiae during fermentation (Yokoya and Oliva-Neto, 1991; Cherubin, 2003). L. plantarum was the most resistant bacterial strain to chlorine dioxide (125 ppm) proposed for the control of bacterial contamination in fermentation (Meneghin et al., 2008). Yeast killer toxin could be a new approach to this control.

In respect to $B$. subtilis, higher resistance to crude toxin preparations was observed. The killer yeasts CCA194, 199 and 417 were more efficient to inhibit this bacterial strain, however, not in the same extent as L. plantarum (Fig. 3). In any case, greater bacterial inhibition was found after yeast log phase. Buzzini et al. (2004) observed a constant increase in toxin production during exponential growth with a peak during early stationary phase for two killer strains. No inhibition zones were found for killer yeasts against $L$. mesenteroides and $L$. fermentum in cell $\mathrm{X}$ cell and crude toxin $\mathrm{X}$ cell tests. 


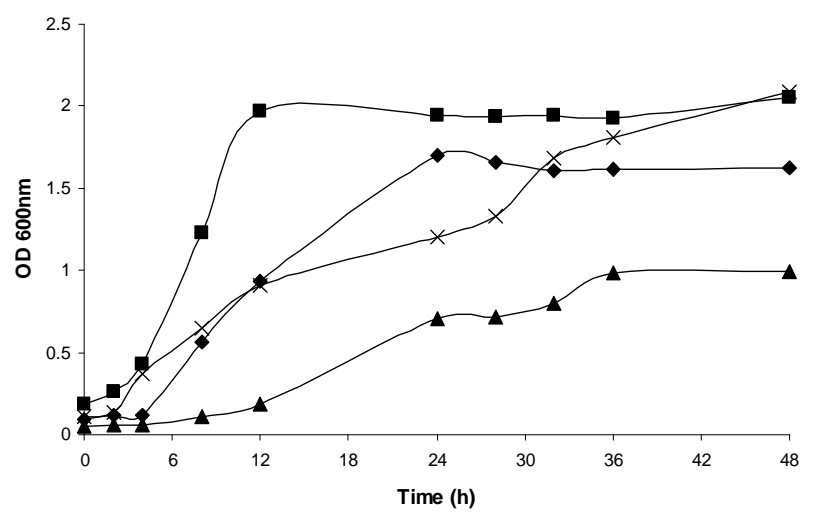

Figure 1 - Growth curves of yeast killer strains ( $\bullet C A 194 ;$ mCCA199; $\Delta$ CCA417; ×CCA630), in buffered-YEPD medium, at $30^{\circ} \mathrm{C}, 40 \mathrm{rpm}$, for two days.
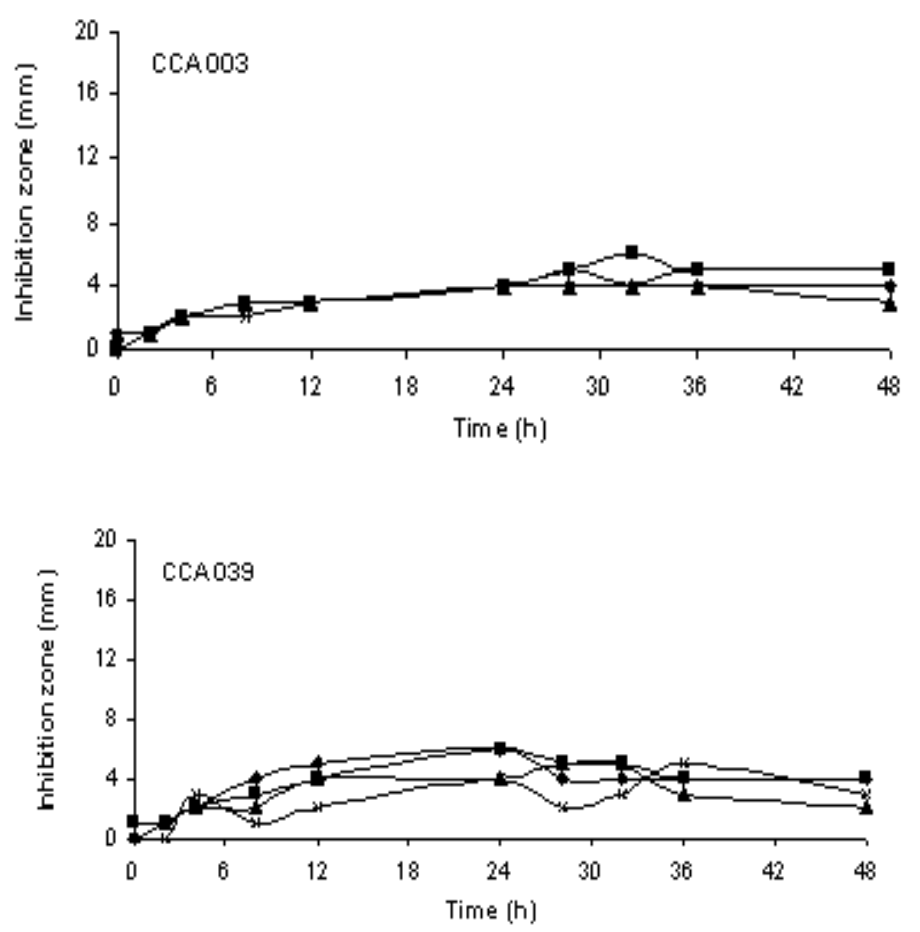

Figure 2 - Inhibition zone $(\mathrm{mm})$ of killer yeast filtrates ( $\bullet$ CCA194; $\mathbf{a C C A} 199$; $\Delta$ CCA417; $\times$ CCA630) against the sensitive strains CCA003 (NCYC1006, Saccharomyces cerevisiae) or CCA039 (ATCC15126, Torulopsis glabrata), in buffered-YEPD-methylene blue medium, at $25^{\circ} \mathrm{C}$, for two days. 

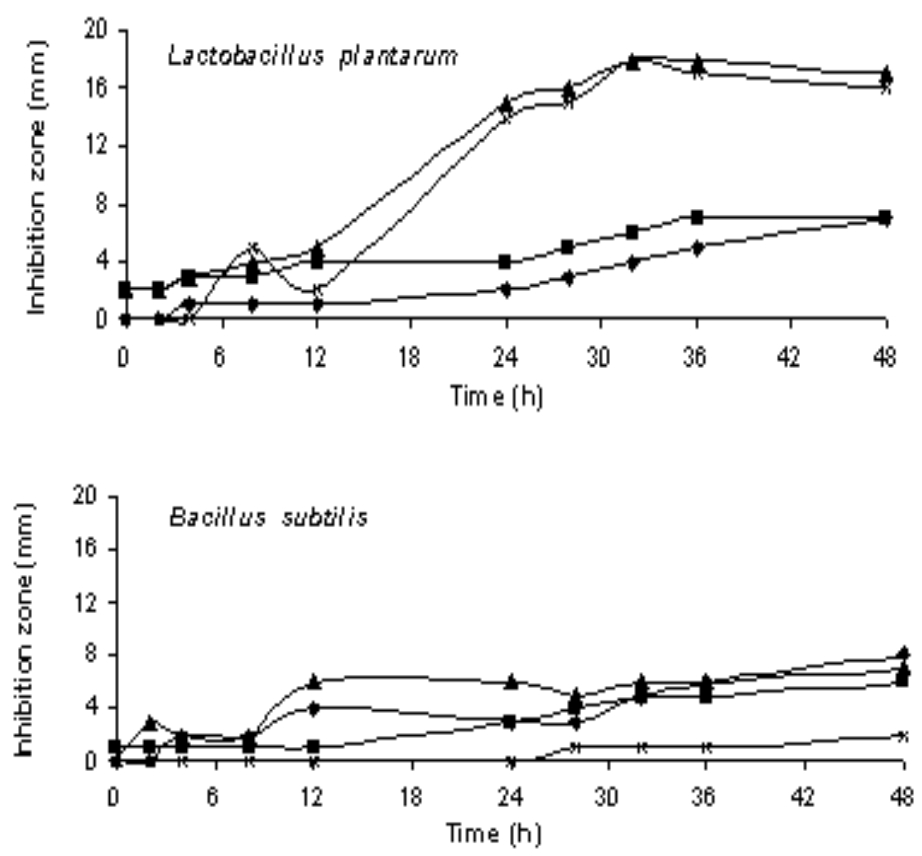

Figure 3 - Inhibition zone $(\mathrm{mm})$ of yeast killer filtrates ( $\bullet$ CCA194; $\square$ CCA199; $\Delta$ CCA417; $\times$ CCA630) against Lactobacillus plantarum and Bacillus subtilis strains, at $25^{\circ} \mathrm{C}$, for two days.

The results suggested that killer activity of yeasts might operate over bacteria and it could be used for the biocontrol of contaminating bacteria from alcoholic fermentation. Additional studies are necessary to evaluate the application of killer toxin preparations into fermentation tanks to control the growth of these microorganisms. Other toxins could be assayed because in this study only toxins from Candida sp, C. glabrata, P. anomala and T. figueirae yeast species were found to be active. Neither dsRNA plasmids nor cure of the killer activity by actidione were detected for these strains (Reis and Ceccato-Antonini, unpublished results), showing a good perspective of stability for purification processes.

Although the inhibition observed here might not necessarily be due to killer toxins because they were not purified but used in crude preparations, the fact that recognized killer yeasts showed toxic activity suggested the involvement of such factor as a promising agent in the bacterial control. A wider panel of $S$. cerevisiae killer yeasts might be used to confirm that they would be really unable to biocontrol these Gram-positive bacteria. This is an undesirable result since these yeasts, as fermentation agents, could be also screened for killer toxin production.

\section{RESUMO}

Este estudo mostrou a atividade antibacteriana in vitro de linhagens de leveduras killer contra bactérias contaminantes da fermentação alcoólica (Bacillus subtilis, Lactobacillus plantarum, Lactobacillus fermentum and Leuconostoc mesenteroides), em testes célula $\mathrm{X}$ célula e célula $\mathrm{X}$ toxina bruta. As bactérias não foram inibidas por linhagens killer de Saccharomyces cerevisiae (5 dentre 11). Os preparados brutos de toxina de duas leveduras (Trichosporon figueirae e Candida sp) causaram uma alta inibição no crescimento de L. plantarum, mas não na mesma extensão para $B$. subtilis, especialmente para três leveduras killer (Candida glabrata, Pichia anomala e Candida sp). Linhagens de L. mesenteroides e L. fermentum não foram inibidas em nenhum dos testes. Os resultados obtidos neste estudo sugerem a ação de toxinas killer de leveduras contra bactérias, a qual poderia ser utilizada para o biocontrole de 
bactérias contaminantes da fermentação alcoólica se testes posteriores de aplicação da toxina dentro das dornas de fermentação se mostrarem eficientes. Um número maior de linhagens killer de $S$. cerevisiae deveria ser utilizado para confirmar se elas realmente são incapazes de controlar o crescimento destas bactérias Grampositivas.

\section{REFERENCES}

Amorim, H.V.; Oliveira, A.J. (1982), Infecção na fermentação: como evitá-la. Álcool e Açúcar, 2 (5), 12-18.

Basso, L.C.; Alves, D.M.G.; Amorim, H.V. (1996), An ecological reason for succinic acid formation by yeast. Paper presented at XI Simpósio Nacional de Fermentações, São Carlos, SP, Brasil.

Bevan, E. A.; Makower, M. (1963), The physiological basis of the killer character in yeast. In- Genetics today, XI International Congress of Genetics, ed. S.J. Geerts, Pergamon Press, Oxford, UK, p.202-203.

Bilinski, C.A.; Innamorato, G.; Stewart, G.G. (1985), Identification and characterization of antimicrobial activity in two yeast genera. Appl. Environ. Microbiol., 50, 1330-1332.

Buzzini, P.; Corazzi, L.; Turchetti, B.; Buratta, M. ; Martini, A. (2004), Characterization of the in vitro antimycotic activity of a novel killer protein from

Williopsis saturnus DBVPG4561 against emerging pathogenic yeasts. FEMS Microbiol. Lett., 238, 359365.

Buzzini, P.; Martini, A. (2001), Large scale screening of selected Candida maltosa, Debaryomyces hansenii and Pichia anomala toxin activity against pathogenic yeasts. Med. Micol., 39, 479-482.

Buzzini, P.; Turchetti, B.; Vaughan-Martini, A. (2007), The use of killer sensitivity patterns for biotyping yeast strains: the state of the art, potentialities and limitations. FEMS Yeast Res., 7, 749-760.

Cherubin, R.A. (2003), Efeitos da viabilidade da levedura e da contaminação bacteriana na fermentação alcoólica. Ph.D. thesis, ESALQ/USP, Piracicaba, SP, Brasil.

Coelho, A.R.; Celli, M.G.; Ono, E.Y.S.; Wosiacki, G.; Hofmann, F.L.; Pagnocca, F.C.; Hirooka, E.Y. (2007), Penicillium expansum versus antagonist yeasts and patulin degradation in vitro. Braz. Arch. Biol. Technol., 50(4), 725-733.
Fuentefria, A.M.; Faganello, J.; Pazzini, F.; Schrank, A.; Valente, P.; Vainstein, M. (2007), Typing and patterns of cellular morphological alteration in Cryptococcus neoformans and Cryptococcus gatti isolates exposed to a panel of killer yeats. Med. Mycol., 45, 1-10.

Fuentefria, A.M.; Perez, L.R.R.,; Azevedo, P.A.; Pazzini, F.; Schrank, A.; Vainstein, M.H.; Valente, P. (2008), Typing of Staphylococcus epidermidis clinical strains by a selected panel of Brazilian killer yeasts. J. Basic Microbiol., 48 (1), 25-30.

Golubev, W.I. (1998), Mycocins (killer toxins). In- The yeasts. A taxonomic study, ed. C.P. Kurtzman and J.W. Fell (eds.). Academic Press, London, UK, p.5562.

Golubev, W.I. (2006), Antagonistic interactions among yeasts. In- The yeast handbook. Biodiversity and ecophysiology of yeasts, ed. C.A. Rosa and P. Gábor (eds.). Springer, Berlin, Germany, p.197-219.

Izgu, F.; Altinbay, D. (1997), Killer toxins of certain yeast strains have potential growth inhibitory activity on Gram-positive pathogenic bacteria. Microbios, 89(358), 15-22.

Izgu, F.; Altinbay, D. (2004), Isolation and characterization of the K5-type yeast killer protein and its homology with an exo-1,3-glucanase. Biosci. Biotechnol. Biochem., 68, 685-693.

Kagan, B. L. (1983), Mode of action of yeast killer toxins: channel formation in lipid bilayers. Nature, 302, 709-711.

Magliani, W.; Conti, S.; Gerloni, M.; Bertolotti, D.; Polonelli, L. (1997), Yeast killer systems. Clin. Microbiol. Rev., 10(3), 369-400.

Meneghin, S.P.; Reis, F.C.; Almeida, P.G.; CeccatoAntonini, S.R. (2008), Chlorine dioxide against bacteria and yeasts from the alcoholic fermentation. Braz. J. Microbiol., 39(2), 337-343.

Michalcakova, S.; Sulo, P.; Slavikova, E. (1993), Killer yeasts of Kluyveromyces and Hansenula genera with potential application in fermentation and therapy. Acta Biotechnologica, 4, 341-350.

Morace, G.; Manzara, S.; Dettori, G.; Fanti, F.; Conti, S.; Campani, L.; Polonelli, L.; Chezzi, C. (1989), Biotyping of bacterial isolates using the yeast killer system. Eur. J. Epidemiol., 5, 303-310.

Nobre, T.P.; Horii, J.; Alcarde, A.R. (2007), Viabilidade celular de Saccharomyces cerevisiae cultivada em associação com bactérias contaminantes da fermentação alcoólica. Cienc. Tecnol. Aliment., 27(1), 20-25. 
Oliva-Neto, P.; Ferreira, M.A.; Yokoya, F. (2004), Screening for yeast with antibacterial properties from an ethanol distillery. Biores. Technol., 92, 1-6.

Palpacelli, V.; Ciani, V.; Rossini, G. (1991), Activity of different killer yeasts on strains of yeast species undesirable in the food industry. FEMS Microbiol. Lett., 68, 75-78.

Polonelli, L.; Morace, G. (1986), Reevaluation of the yeast killer phenomenon. J. Clin. Microbiol., 24(5), 866-869.

Provost, F.; Polonelli, L.; Conti, S.; Fisicaro, P. ; Gerloni, M. ; Boiron, P. (1995), Use of yeast killer system to identify species of the Nocardia asteroides complex. J. Clin. Microbiol., 33, 8-10.

Rodini, M.A.T. (1985), Isolamento, caracterização e identificação de bactérias contaminantes de dornas de fermentação nas destilarias de etanol. M.Sc.Dissertation,ESALQ/USP, Piracicaba, SP, Brasil.

Sasaki, T.; Watari, J.; Kohgo, M.; Nishikawa, N.; Matsui, Y. (1984), Breeding of a brewer's yeast possessing anticontaminant properties. Proc. Am. Soc. Brew. Chem., 42, 164-166.
Sawant, A.D.; Abdelal, A.T.; Ahearn, D.G. (1989), Purification and characterization of the antiCandida toxin of Pichia anomala WC 65. Antimicrob. Agents Chemother., 33, 48-52.

Silva, N. (1988), Influência do resfriamento em torres sobre a microflora do caldo de cana no processo de produção de álcool. M.Sc. Dissertation, Unicamp, Campinas, SP, Brasil.

Tosta, C. D. (2004), Biotipagem de leveduras industriais através do sistema killer. M.Sc. Dissertation, ESALQ/USP, Piracicaba, SP, Brasil.

Wheals, E.A.; Basso, L.C.; Alves, D.M.G.; Amorim, H.V. (1990), Fuel ethanol after 25 years. Trends Biotechnol., 17, 482-487.

Yokoya, F.; Oliva-Neto, P. (1991), Characteristics of yeast flocculation by Lactobacillus fermentum. Rev. Microbiol., 22, 21-27.

Young, T. W.; Yagiu, M. (1978), A comparison of the killer character in different yeasts and its classification. Antonie van Leewenhoek J. Microbiol. Serol., 44, 59-77.
Received: March 03, 2009; Revised: June 10, 2009; Accepted: February 12, 2010. 